\title{
The Exposure Rate Of Existing Shareholders, Underpricing And IPO Withdrawals At Borsa Istanbul: A Special Look At Opportunity Cost Of Issuance
}

\author{
Orhan Emre Elma \\ Faculty of Applied Sciences, \\ Necmettin Erbakan University, Konya, TR.
}

\begin{abstract}
Capital markets play a key role in achieving the medium and long-term goals of companies to reach the point of comparison with their competitors in the world. Capital markets journey, which is so important for companies, can also be called a life and death war. Not every issuance application to regulators results in a positive outcome. Turkey is the third country that is experiencing the most IPO withdrawal, according to Bennouna's (2015) study. Reasons such as wrong timing of the issuance or not being able to create positive sentiment among stakeholders cause issuance withdrawals. Companies aim to guarantee the earnings of their first partners in the long term rather than bringing immediate positive returns for their new investors. For this reason, the damage suffered by the first partners in IPO is an important parameter in understanding capital markets, along with underpricing. In this study, 76 public offerings in Borsa Istanbul between 2005 and 2015 were examined according to Dolbin's (2013) methodology. The discount rate applied by the companies during this period is $22.86 \%$, while the underpricing rate applied is around $4.3 \%$. Results show that, opportunity cost of issuance, which is the loss suffered by the first partners is found to be only $1.3 \%$ at Borsa Istanbul. Also, the relationship between underpricing and opportunity cost of issuance is found to be $74.7 \%$. The withdrawal rate have positive correlations of $36.6 \%$ and $40.4 \%$ with firm age and cost per share, respectively. Results also indicates that, withdrawal rates starts to diminish at hot markets when average market volatility rises.
\end{abstract}

Keywords: Initial Public Offering; Opportunity Cost of Issuance; Underpricing; Withdrawals.

\section{INTRODUCTION}

Initial Public Offering has been studied for decades. The underpricing of IPOs has been under the scope since the study of Stoll and Curley [1]. From then on, more researchers have been questioning the reasons behind underpricing of IPOs starting from US, and shortly after other developed and developing countries [2-7].

The effect of the information obtained from the prospectuses and financial ratios on the final public offering price has been investigated in previous studies. Kim et al. [8] found evidence that the IPO bid price was significantly affected by variables such as earnings per share, proposal size, sector estimates and bid type. Klein [9] also mentioned the importance of variables related to the prospectus and concluded that past accounting information has a key role in pricing IPOs. Kim and Ritter [10], on the other hand, stated that accounting variables do not have much effect on their own, and when used together with the predicted earnings for the following year, they affect IPO price more.

According to Engelen and van Essen [11], the legal infrastructure of a country significantly reduces underpricing. In contrast, Boulton [12] states that underpricing is higher in countries 
where corporate finance is developed. In general, country-specific differences seem to be used as an indicator for explaining international underpricing.

In the studies carried out on IPOs, the portion of the company's shares held by stockholders before entering the market [13], information asymmetry, financial structure and financial mediation [14], income estimates at publicly available prospectuses were examined [15]. In the empirical literature on IPO valuation, the percentage of retained shares plays an important role. The presence of a strong positive relationship between preexisting shares and initial firm value was also reported at the studies of Ritter [16], and Li and McConomy [17].

Petersen and Rajan [18] and Shleifer and Vishny [19], stated that credit market growth and firm-lender relationship may affect the financial costs of a firm. Schenone [20], on the other hand, deduced that companies that have an established relationship with banks are subject to less underpricing when compared to companies who don't have an efficient relationship with them. Therefore, these banks experience less information asymmetry than IPO firms. Crosscountry studies show that the legal system plays an important role in the differences between IPO underpricing in different markets $[12,21]$. Finally, Jones et al. [22] reported that less government intervention is associated with less underpricing.

Companies are eager to take advantages of having more capital partners by going public, however for a number of firms some strategies don't go well as planned at this process. Looking at the literature in general, it seems obvious that firms especially consider the withdrawal costs during their initial public offering processes. At this study, the opportunity cost of issuance at Borsa Istanbul is examined in order to clarify the weight of public offerings on preexisting shareholders, and underline the differences between underpricing and cost of issuance.

\section{WITHDRAWN IPOS AND EXPOSURE RATE OF EXISTING SHAREHOLDERS}

Issuance process is stressful for plenty of companies because while they try to increase their recognition, prestige, credibility and profitability, offering operation may not go as expected. The changing economic conditions of the industry or company which can cause misevaluations [23], negative information cascades about the issuer firm [24], and shifting investor perceptions can cause withdrawals of IPOs. So, the financial market journey of the company finishes even before it begins. But cost overrun is not finished yet. According to a study, a firm's initial public offering withdrawal causes serious expenditures for the firm, thus makes it difficult for investors to trust enough to invest when it is listed again in the capital markets afterwards [25].

Dunbar [26] examined a total of 3540 successful and failed IPOs, which occurred between 1984 and 1993. Benveniste et al. [27] also analyzed IPOs listed between 1985 and 2000 and observed the effect of information spillover. The most important variable that emerged in that study was found to be the market share of the leading investment bank, which was effective in the initial public offering. The initial public offerings mediated by more prestigious investment banks were found to be mostly successful. Another finding of that study is that the firms that are overvalued are experiencing more initial public offering withdrawals.

At two studies based on US IPOs covering the period of 1985 through 2000, the withdrawal rate is found to be $20 \%[28,29]$. In his study, Bennouna [30] investigated how much of the initial IPO applications were successfully completed. 13,751 IPOs from 31 countries listed between 2003 and 2010 are examined at the study. The result is that $23.4 \%$ of IPOs are not actualized. The top 3 countries who experience more withdrawals on their public offerings are 
Russia with $72.7 \%$, Spain with $48.6 \%$, and Turkey with $47.7 \%$, as seen on Table 1 . At the list, the country with the least IPO withdrawal occurrence is Japan with a rate of just $2.1 \%$. The strict regulatory control on the first listings at Japanese financial markets have proven to be effective.

Unlike the efficient IPO market in United States, it is more difficult to enter stock markets in Japan. Companies have to had a net positive income before going public. For this reason, in order to enter the capital markets, most companies apply formulas that will further increase their net incomes. Investors will not prefer young firms' initial public offerings without transparent earnings, especially when they are not underpriced enough. From this point of view, although underpricing has been felt in Japanese stock markets around $41.70 \%$ in recent years [7], the IPO rate which is not realized due to the difficulty of entering capital markets is at the bottom of the list with $2.1 \%$. Because of these requirements, Japanese IPO companies also have efficient operational productivity and excellent performance before issuance, on paper. Unlike companies in US capital markets with about $40 \%$ negative net income, almost none of the new publicly traded firms in Japan have negative incomes. In addition, the average age of companies opening to capital markets is almost 3 times older than companies in the USA [31]. 
Table 1: Withdrawn IPOs According to Country

\begin{tabular}{|c|c|c|c|c|}
\hline Country & Successful IPOs & Withdrawn IPOs & Total IPOs & Withdrawal Rate (\%) \\
\hline Australia & 1,031 & 165 & 1,196 & 13.80 \\
\hline Belgium & 63 & 15 & 78 & 19.20 \\
\hline Brazil & 115 & 73 & 188 & 38.80 \\
\hline Canada & 1,106 & 148 & 1,254 & 11.80 \\
\hline China & 1,293 & 366 & 1,659 & 22.10 \\
\hline Denmark & 39 & 15 & 54 & 27.80 \\
\hline England & 782 & 160 & 942 & 17.00 \\
\hline France & 287 & 43 & 330 & 13.00 \\
\hline Germany & 147 & 81 & 228 & 35.50 \\
\hline Greece & 56 & 12 & 68 & 17.60 \\
\hline Hong Kong & 316 & 59 & 375 & 15.70 \\
\hline India & 393 & 193 & 586 & 32.90 \\
\hline Indonesia & 88 & 75 & 163 & 46.00 \\
\hline Israel & 52 & 34 & 86 & 39.50 \\
\hline Italy & 101 & 69 & 170 & 40.60 \\
\hline Japan & 849 & 18 & 867 & 2.10 \\
\hline Malaysia & 335 & 33 & 368 & 9.00 \\
\hline Netherlands & 36 & 29 & 65 & 44.60 \\
\hline New Zealand & 56 & 10 & 66 & 15.20 \\
\hline Norway & 96 & 25 & 121 & 20.70 \\
\hline Poland & 241 & 123 & 364 & 33.80 \\
\hline Russia & 38 & 101 & 139 & 72.70 \\
\hline Singapore & 238 & 45 & 283 & 15.90 \\
\hline South Korea & 613 & 45 & 658 & 6.80 \\
\hline Spain & 38 & 36 & 74 & 48.60 \\
\hline Sweden & 66 & 34 & 100 & 34.00 \\
\hline Switzerland & 43 & 9 & 52 & 17.30 \\
\hline Taiwan & 457 & 44 & 501 & 8.80 \\
\hline Thailand & 186 & 60 & 246 & 24.40 \\
\hline Turkey & 45 & 41 & 86 & 47.70 \\
\hline USA & 1,333 & 1,051 & 2,384 & 44.10 \\
\hline Total & 10,539 & 3,212 & 13,751 & 23.40 \\
\hline
\end{tabular}

Source: Bennouna, K. (2015). IPO Failures Around the World, The School of Economics and Finance, Faculty of Business, Queensland University of Technology.

Most companies generally describe their withdrawals with mistiming of issuances and inappropriate market conditions. Another possible reason for withdrawing is the 
dissatisfaction of companies' first partners by the market value given to their firm. Setting the offering price low and having a positive first trading day, which can be defined as underpricing, is not popular around Russian companies. Regardless of the issuance place whether they take place in the original country or in other countries, especially foreign investors are very cautious towards the issuance of Russian companies, and as a consequence this situation does not create a positive investor sentiment for the public offering. On the other hand, companies overstate their financial performance indicators in order to attract more investors, which seriously undermines investors' confidence in Russian stocks [32]. From this point of view, the indispensable positive connection, which cannot be established with investors, makes it difficult for Russian companies to enter capital markets. As seen in the list, the country with the most unsuccessful IPO is Russia with $72.70 \%$. In another study, it is seen that the lowest average underpricing of initial public offerings is yet again in Russia with $3.30 \%$ compared to 52 other countries' capital markets [33].

IPO withdrawals between 2011 and 2015 is found to be $64.8 \%$ at Borsa Istanbul. Especially between 2013 and 2015 ipo withdrawals are harsh, as seen on Figure 1. It was 76\% for 2013, $81 \%$ for 2014 and $87 \%$ for 2015 . According to a study about unsuccessful public offerings in Turkey, $60.7 \%$ of the issuances choose to withdraw because of the cost of issuances and the heavy weight of underpricing on first partners [34].

Figure 1: IPO Withdrawals in Borsa Istanbul Between 2013 - 2015

IPO Withdrawals in Turkey

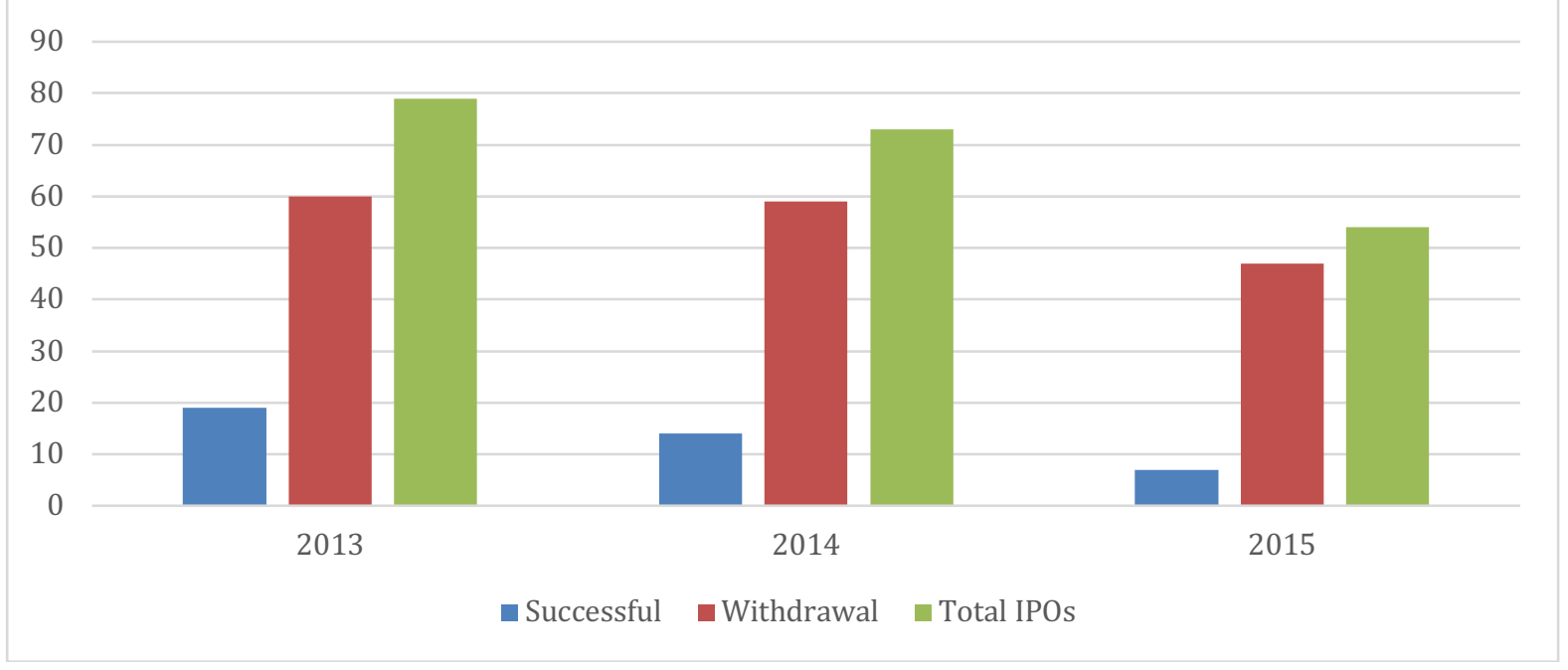

The major goal of issuing companies is to maximize preexisting shareholders benefits. Ironically, the vast majority of the researches on public offerings focused on underpricing. In order to help the needs of preexisting shareholders, companies' should make strategies to minimize their shares' opportunity of issuances, not underpricing.

The money left on the table at public offering is very important for present partners of the company, in order to accomplish their long term strategies in maintaining a sustainable benefit for the foresesable future. The price of newly issued shares should be both attractive enough to cover companys' issuance goals and lure long run investors.

Discounts are applied to newly issued shares with the objective to draw more investors, but this conjuncture disturbs many partners. Generally, companies wishing to enter the capital markets for big ambitions are preparing for public offerings within the limits set by regulators, 
while the process may result in withdrawal due to the negative perception that occurs in the market within stakeholders. From this perspective, it would be more accurate for companies to focus on the opportunity cost of issuance rather than underpricing. For instance, the underpricing and opportunity cost of issuances in US between 1990-1998 are 16.29\% and $5.18 \%$, and between $2001-2004$ are $10.99 \%$ and $4.00 \%$ respectively [35].

Although issuance is so important for companies, the fact that most of the offerings don't result successfully is an issue that needs to be examined in order to understand the characteristics of different capital markets. The costs to be undertaken by the preexisting partners are not generally analyzed under a separate title in the literature, instead underpricing is scrutinized. The withdrawal rate of Turkish IPOs and the relationship between underpricing and opportunity cost of issuances at Borsa Istanbul are analyzed in this study.

\section{METHODOLOGY}

76 IPOs from all sectors except finance industry listed at Borsa Istanbul between 2005 and 2015 are analyzed in order to clarify the difference between underpricing and opportunity cost of issuance. The closing prices of IPOs are provided from FINNET BIST Terminal; the number of shares offered, internal shares offered, and preexisting shares are taken from company's prospectuses at Public Disclosure Platform of Turkey. The mean IPO underpricing is at the level of $4.3 \%$, while the average discount rate that applied by firms at the initial public offering process is found to be $22.86 \%$. In addition, average firm age at the time of issuance is 17.46 , for IPOs at this particular time frame. The closing prices are taken from 2005 until 2020 in order to observe if opportunity cost of issuance has a long-term effect on IPOs.

The aim here is to measure the sacrifices that the first partners will have to make at the issuance, while company tries to fulfill the goals in the future, with the momentum created from the offering. The fact that the weight of entering the capital markets and the public offering cost seem to be excessive in the first place prevents the companies from initiating the issuance. For this reason, the relationship between the sacrifices of the first partners and the IPO withdrawal rates will also be examined in order to see the broader picture. In accordance with the study of Dolvin [35], the issuances' opportunity cost (OCI) was calculated with the formula below:

$$
\text { Opportunity Cost of Issuance }=\frac{P_{1}-\text { Offering Price } *(\text { Shares Offered })}{P_{1} * \text { Existing Shares }+\left(P_{1}-\text { Offering Price }\right) * \text { Primary Shares }}
$$

When the initial public offerings at Borsa Istanbul are analyzed, it is seen that the issuance prices of companies vary between 1.65 and 36.80 of and the average supply price is 5.12 . On the other hand, it is observed that the companies had 36 million shares before the public offering, and the primary was listed on Borsa Istanbul with 6.9 million, and 3.3 million shares, on average. The average number of shares offered to the public is 10.2 million. As seen on Table 2 below, the issuance weight on preexisting shareholders is found to be only $1.3 \%$ for the IPOs at the given period, while underpricing is found to be at the level of $4.3 \%$. 
Table 2: The Descriptive Statistics of the IPOs listed between 2005 and 2015 period

\begin{tabular}{|l|c|c|c|c|c|c|c|c|}
\hline & $\begin{array}{c}\text { New Shares } \\
\text { Offered }\end{array}$ & $\begin{array}{c}\text { Secondary } \\
\text { Shares } \\
\text { Offered }\end{array}$ & $\begin{array}{c}\text { Primary } \\
\text { Shares } \\
\text { Offered }\end{array}$ & $\begin{array}{c}\text { Preexisting } \\
\text { Shares }\end{array}$ & $\begin{array}{c}\text { IPO } \\
\text { Price }\end{array}$ & $\begin{array}{c}\text { First } \\
\text { Day } \\
\text { Closing }\end{array}$ & $\begin{array}{l}\text { Underp. } \\
\text { OCI }\end{array}$ \\
\hline Mean & 10183806.9 & 3303402.4 & 6880404.6 & 35990068.6 & 5.1280 & 5.2684 & .043371 & .013092 \\
\hline $\begin{array}{l}\text { Std. } \\
\text { Deviation }\end{array}$ & 14437868.5 & 8510361.7 & 11770317.6 & 76446300.1 & 5.02 & 4.94 & .094 & .060 \\
\hline Minimum & 353320 & .00 & .00 & 596680 & 1.65 & 1.90 & -.1729 & -.1194 \\
\hline Maximum & 86000000 & 50322321 & 86000000 & 550000000 & 36.80 & 34.75 & .2171 & .3676 \\
\hline
\end{tabular}

Only three companies during the period have bigger OCI's when compared to their first day performance, according to Table 3. Actually 'Armada' is overpriced, while 'Datagate' and 'Reysas' are underpriced. The first day closing effect of these companies are bigger when compared to others, because they offered exorbitantly more shares than their preexisting shares. This strategy enhanced the issuance cost on first partners, so as a consequence this approach is not implemented by other initial public offerings which took place after 2006. Every other issuance that take place after this year, made the issuance cost more smoother for the first partners of the IPO companies at Borsa Istanbul. 
Table 3: Opportunity Cost of Issuance at IPOs in Borsa Istanbul

\begin{tabular}{|c|c|c|c|c|c|c|c|}
\hline Firms & $\begin{array}{c}\text { Total Shares } \\
\text { Offered }\end{array}$ & $\begin{array}{l}\text { Existing } \\
\text { Shares }\end{array}$ & $\begin{array}{c}\text { OCI } \\
\text { (Opportunity } \\
\text { Cost of } \\
\text { Issuance }\end{array}$ & Firms & $\begin{array}{c}\text { Total Shares } \\
\text { Offered }\end{array}$ & Existing Shares & $\begin{array}{c}\text { OCI } \\
\text { (Opportunity } \\
\text { Cost of } \\
\text { Issuance }\end{array}$ \\
\hline ANELT & $9,000,000$ & $13,000,000$ & 0.011 & OYLUM & $2,750,000$ & $6,875,000$ & 0.067 \\
\hline BIMAS & $9,487,509$ & $25,300,000$ & 0.022 & PRZMA & $3,600,000$ & $10,000,000$ & -0.003 \\
\hline TSPOR & $6,250,000$ & $25,000,000$ & -0.005 & ORGE & $3,000,000$ & $7,000,000$ & -0.040 \\
\hline ARMDA & $9,325,000$ & $6,750,000$ & -0.109 & MEGAP & $4,000,000$ & $9,221,450$ & 0.016 \\
\hline CCOLA & $50,322,321$ & $249,589,770$ & 0.020 & MCTAS & 771,000 & $4,370,000$ & 0.017 \\
\hline DGATE & $5,050,000$ & $1,550,000$ & 0.368 & TKNSA & $11,000,000$ & $99,000,000$ & -0.002 \\
\hline KAREL & $4,900,000$ & $14,000,000$ & -0.007 & ARTOG & $8,050,000$ & $14,450,000$ & 0.089 \\
\hline RYSAS & $46,500,000$ & $35,000,000$ & 0.215 & TGSAS & $2,500,000$ & $5,000,000$ & -0.009 \\
\hline SELEC & $39,150,000$ & $200,000,000$ & 0.034 & FLAP & $4,000,000$ & $23,000,000$ & 0.024 \\
\hline VESBE & $52,000,000$ & $138,000,000$ & 0.000 & AKGUV & $1,500,000$ & $11,000,000$ & 0.016 \\
\hline TAVHL & $38,750,000$ & $232,500,000$ & 0.015 & ETILR & $2,500,000$ & $5,000,000$ & -0.029 \\
\hline KOZAL & $18,000,000$ & $60,000,000$ & -0.018 & ULAS & $3,500,000$ & $9,157,000$ & 0.053 \\
\hline LATEK & $8,000,000$ & $26,000,000$ & 0.013 & KRATL & $16,750,000$ & $50,000,000$ & 0.000 \\
\hline MANGO & $3,400,000$ & $6,600,000$ & 0.040 & ATPET & $1,950,000$ & $4,050,000$ & -0.007 \\
\hline AKSEN & $86,000,000$ & $550,000,000$ & -0.005 & TKURU & 353,320 & 596,680 & -0.051 \\
\hline IHGZT & $26,400,000$ & $80,000,000$ & 0.043 & TMSN & $30,000,000$ & $105,000,000$ & 0.001 \\
\hline ANELE & $16,000,000$ & $30,600,000$ & 0.000 & ROYAL & $15,000,000$ & $50,000,000$ & 0.000 \\
\hline CEMAS & $8,250,000$ & $15,000,000$ & 0.043 & TACTR & $1,500,000$ & $4,000,000$ & 0.027 \\
\hline EKIZ & $2,846,250$ & $5,500,000$ & -0.119 & ODAS & $12,000,000$ & $30,000,000$ & 0.003 \\
\hline UYUM & $10,000,000$ & $10,000,000$ & -0.053 & BAKAN & $1,000,000$ & $2,300,000$ & 0.070 \\
\hline KATMR & $3,000,000$ & $11,000,000$ & -0.006 & AKPAZ & $16,500,000$ & $32,586,740$ & -0.010 \\
\hline DESPC & $4,525,000$ & $11,000,000$ & 0.006 & SAYAS & $5,000,000$ & $16,000,000$ & 0.011 \\
\hline HATEK & $3,250,000$ & $18,800,000$ & 0.030 & RODRG & $2,000,000$ & $4,800,000$ & 0.040 \\
\hline LKMNH & $2,782,500$ & $11,130,000$ & 0.030 & SEKUR & $3,000,000$ & $10,885,000$ & 0.002 \\
\hline BRKSN & $4,000,000$ & $4,000,000$ & -0.048 & YAYLA & $2,500,000$ & $6,850,000$ & 0.060 \\
\hline UTPYA & $10,000,000$ & $20,000,000$ & -0.079 & IZTAR & $2,989,000$ & $3,661,000$ & 0.003 \\
\hline BMEKS & $18,000,000$ & $46,000,000$ & 0.003 & SANEL & $3,300,000$ & $8,500,000$ & -0.012 \\
\hline BLCYT & $9,926,680$ & $20,073,320$ & -0.007 & TMPOL & $1,250,000$ & $4,000,000$ & 0.004 \\
\hline DAGI & $10,135,550$ & $18,864,450$ & 0.082 & POLTK & 750,000 & $3,000,000$ & 0.004 \\
\hline ERICO & $2,250,000$ & $4,000,000$ & 0.077 & RTALB & $2,000,000$ & $4,800,000$ & -0.015 \\
\hline MEPET & $5,000,000$ & $50,000,000$ & 0.003 & BMELK & $3,400,000$ & $13,600,000$ & 0.010 \\
\hline SAMAT & $3,600,000$ & $8,600,000$ & 0.068 & TUCLK & $7,000,000$ & $25,000,000$ & 0.009 \\
\hline VANGD & $8,950,000$ & $11,050,000$ & 0.000 & IZFAS & $3,200,000$ & $7,250,000$ & 0.016 \\
\hline OZBAL & $7,000,000$ & $15,800,000$ & -0.021 & PSDTC & $1,480,000$ & $3,020,000$ & -0.021 \\
\hline ADESE & $8,817,199$ & $21,182,801$ & -0.019 & ULUUN & $23,500,000$ & $65,000,000$ & -0.013 \\
\hline NIBAS & $5,000,000$ & $22,000,000$ & 0.037 & OZRDN & $1,750,000$ & $7,010,000$ & 0.011 \\
\hline SANFM & $4,750,000$ & $6,550,000$ & -0.028 & SENKRN & $2,680,000$ & $5,500,000$ & 0.000 \\
\hline BEYAZ & $3,528,000$ & $32,722,000$ & -0.001 & SEYKM & $1,800,000$ & $6,600,000$ & 0.018 \\
\hline
\end{tabular}

Companies prefer to offer primary shares rather than secondary in order to generate more capital from new investors. Except for five companies, all public offerings happened with primary share offering. Overpricing is observed for 27 firms while underpricing is effective for 49 firms in this period. Opportunity cost of issuance is found to be $1 \%$ at $2005,7.4 \%$ at 2006 , $1.5 \%$ at 2007 , and on average $0.6 \%$ from 2010 to 2015. Because of the financial crisis of 2008 at US, there were no initial public offerings happened at the aforementioned sectors of this 
study in Borsa Istanbul until 2010. Even though OCI dropped rapidly after this year, underpricing is still felt around 3.8\% at the capital markets of Turkey.

According to Table 4, there is a $74.7 \%$ positive relationship between underpricing and opportunity cost of issuance, which is significant at 0.01 level. If a share is underpriced more at issuance, that shares' opportunity cost for preexisting partners has a tendency of increasing at the issuance day at Borsa Istanbul. First partners have a right to fear from underpricing, because of the positive effect of it on cost of issuance. Although underpricing enhances the weight of issuance on first partners shoulders, it should be noted that OCI is seriously smaller than underpricing. Also there is a $-26.5 \%$ negative correlation between OCI and third year share return after issuance. This finding shows that, if the weight of issuance cost on first partners rises, it creates a negative effect on third year share returns of the companies. The new investors examine bigger companies at their third trading years, so as a result share returns diminish.

Table 4: Relationship Between Underpricing, 3rd Year Share Return and Opportunity Cost of Issuances at IPOs in Borsa Istanbul Opportunity Cost of Issuance (OCI)

$\begin{array}{lc}\text { Underpricing } & 0.747 \\ \text { 3rd Year Share Return } & 0.000^{* * *} \\ -.265 \\ 0.021^{* *}\end{array}$

As mentioned before withdrawal rates have risen especially at the period of 2013 and 2015 . But when analyzed, there is not a significant relationship found between the number of withdrawals and underpricing or cost of issuance. However, it has a positive $36.6 \%$ and $40.4 \%$ correlations with firm age and cost per share respectively, with the significance of 0.10 , as seen on Table 5. Results show that, younger companies choose to give up on their public offerings at the periods of prestigious firms' costly offerings, and wait for more suitable market timing, even though it is more costly for firms to try public offerings for a second time. Speaking of which, the suitable market timing is found to be the time where market volatility is higher. The number of withdrawals have a correlation of $-44.7 \%$ with the average market volatility, which is significant at 0.05 level.

Table 5: Relationship Between the Number of Withdrawals and Firm Age, Cost per Share, Average Market Volatility

\begin{tabular}{lccc} 
& Firm Age & Issuance Cost per Share & Average Market Volatility \\
\hline The Number of & 0.366 & 0.404 & -0.447 \\
Withdrawals & $0.094^{*}$ & $0.062^{*}$ & $0.037^{* *}$
\end{tabular}

When the results are analyzed, it can be said that increasing amount of underpricing enhances the expenditures of preexisting partners in Turkey. Particularly young companies aiming to prepare for offering, prefer to withdraw because they have to bear not only the expenditure of issuance but also the cost of underpricing. Because of well-established and prestigious companies always want to be seen in the portfolios of Turkish shareholders, small companies choose to wait for hot market times when there is more volatility which occurs with more trading waves by investors.

\section{DISCUSSION AND CONCLUSION}

Contrary to popular belief, the main motivation for companies to realize initial public offering is not to attract more investors in the first place, but to reach the capital that will satisfy the current investors in the medium and long term with the minimum cost. For this purpose, when 
studies on the first public offerings worldwide are examined, it can be said that underpricing maintains its popularity. However, the first partners of the companies can increase the issuance costs in their perspectives and this can cause many public offerings to end even before it takes place at the capital market. Not to mention, it is often more costly for companies to attempt a public offering for the second time [25].

IPO costs of the first partners are one of the issues addressed in the capital markets literature. Although some studies have been done since Leland and Pyle's [13] study of the first partners' share retention analysis, this issue has not been covered enough compared to the underpricing literature. Although 4.3\% underpricing was realized in the period given in the study on Borsa Istanbul, the loss suffered by the first partners is almost one third of underpricing, with $1.3 \%$. Compared with underpricing, this difference is compatible with previous studies [35, 36]. But still, according to the results, an increase in underpricing makes also OCI to rise. The long-term effect of the issuance cost on preexisting partners' shoulders also examined in this study. There is a negative relationship between OCI and third year share return, which means investors at Borsa Istanbul are tend to remove the bigger companies shares from their portfolios, at third year of issuances. Investors would like to observe newly listed big companies' performances from a distance, especially after lock-up agreement ends.

Withdrawal rate between 2011 and 2015 is found to be $64.8 \%$, it is significantly risen when compared to $47.70 \%$ between 2003 and 2010. It can be seen that 2008 financial crisis has made regulators of Turkey to organize markets more effectively. But this made companies to enter Borsa Istanbul even more difficult, especially for younger companies. This study showed that younger firms wait for the perfect time of issuance. By making the issuances at the right time, they pursue the strategy of both reducing the cost of offering for partners and enhancing their transaction volume at the first weeks of listing. Due to these tactics of young companies, an increase in the withdrawal rate has been observed in the recent years. Withdrawal rate rises when older companies are entering to Borsa Istanbul with bigger issuance cost per shares. But whenever average market volatility rises, this creates a decrease in withdrawals. In consequence, results show that, smaller and younger companies which are aiming to be listed in Borsa Istanbul wait for hot market times to make their issuances more favorable for new investors.

Further research can focus on the opportunity cost of public offering rather than underpricing. Medium and long-term performances of stocks, which cost more to the first shareholders during the issuance, can be examined. Regression analysis explaining the cost of first partners can be made. Cross-country studies can be carried out to reveal the relationship between underpricing and issuance cost of first partners. The relationship between withdrawn IPOs and OCI can also be explored at different regions in the world. Furthermore, how the cost that partners have to tolerate on the first day has shaped the future of the company can be analyzed with the studies that will include the finance sector within a longer period.

\section{References}

Stoll, H., and A. Curley, Small Business and the New Issues Market for Equities, The Journal of Financial and Quantitative Analysis, 1970, 5(3): p. 309-322.

Carter, R. and S. Manaster, Initial Public Offerings and Underwriter Reputation, The Journal Of Finance, 1990, 45(4): p. 1045-1067.

Aggarwal, R., and P. Rivoli, Fads in Initial Public Offering Market, Financial Management, 1990, 19: p. 45-57.

Levis, M., The Long Run Performance Of Initial Public Offerings: The U.K. Experience 1980-1988, Financial Management, 1993, 22: p. 28-41. 
Elma, O. E. (2020). The Exposure Rate Of Existing Shareholders, Underpricing And IPO Withdrawals At Borsa Istanbul: A Special Look At Opportunity Cost Of Issuance. Advances in Social Sciences Research Journal, 7(3) 150-161.

Kıymaz, H., The Initial and Aftermarket Performance of IPOs in an Emerging Market: Evidence from Istanbul Stock Exchange, Journal of Multinational Financial Management, 2000, 10: p. 213- 227.

Durukan, M.B., The Relationship between IPO Returns and Factors Influencing IPO Performance: Case of the Istanbul Stock Exchange, Managerial Finance, 2002, 28: p. 18-38.

Ritter, J.R., Differences between European and American IPO Markets, European Financial Management, 2003, 9(4): p. 421-434.

Kim, J., Krinsky, I., and J. Lee, The Role of Financial Variables in the Pricing of Korean Initial Public Offerings, PacificBasin Finance Journal, 1995, 3: p. 449-464.

Klein, A., Can Investors Use the Prospectus to Price Initial Public Offerings?, The Journal of Financial Statement Analysis, 1996, 2: p. 23-29.

Kim, M., and J. Ritter, Valuing IPOs, Journal of Financial Economics, 1999, 53: p. 409-437.

Engelen, P.J. and M. van Essen, Underpricing of IPOs: Firm, Issue and Country-Specific Characteristics, Journal of Banking and Finance, 2010, 34(8): p. 1958-1969.

Boulton, T.J., Smart, S.B., and C.F. Zutter, Earnings Quality and International IPO Underpricing, Accounting Review, 2011, 86(2): p. 483-505.

Leland, H., and D. Pyle, Information Asymmetries, Financial Structure and Financial Intermediation, Journal of Finance, 1977, 32: p. 371-387.

Welch, I., Seasoned Offerings, Imitation Costs, and the Underpricing of Initial Public Offerings, Journal of Finance, 1989, 44: p. 421-449.

Trueman, B., Why Do Managers Voluntarily Release Earnings Forecasts, Journal of Accounting and Economics, 1986, 8(1): p. 53-71.

Ritter, J.R., The 'Hot Issue' Market of 1980, The Journal of Business, 1984, 57(2): p. 215-240.

Li, Y., and B.J. McConomy, Simultaneous Signalling in IPOs via Management Earnings Forecasts and Retained Ownership: An Empirical Analysis of the Substitution Effect, Journal of Accounting, Auditing \& Finance, 2004, 19(1): p. 1-28.

Petersen, M.A., and R.G. Rajan, The Benefits of Lending Relationships: Evidence from Small Business Data, Journal of Finance, 1994, 49: p. 3-37.

Shleifer, A., and R. Vishny, A Survey of Corporate Governance, Journal of Finance, 1997, 52: p. 737-783.

Schenone, C., The Effect Of Banking Relationships On The Firm's IPO Underpricing, Journal of Finance, 2004, 59: p. 2903-2958.

Hopp, C., and A. Dreher, Do Differences in Institutional and Legal Environments Explain Cross-Country Variations in IPO Underpricing?, 2007, Working Paper, University of Konstanz: Konstanz, Baden-Württemberg, DEU

Jones, S.L., et al., Share Issue Privatizations as Financial Means to Political and Economic Ends, Journal of Financial Economics, 1999, 53: p. 217-253.

Mikkelson, W., and M. Partch, Withdrawn Security Offerings, Journal of Financial and Quantitative Analysis, 1988, 23: p. 119-133.

Welch, I., Sequential Sales, Learning, and Cascades, Journal of Finance, 1992, 47: p. 695-732.

Lerner, J., Venture Capitalists and the Decision to Go Public, Journal of Financial Economics, 1994, 35: p. $293-316$.

Dunbar, C., The Choice Between Firm-Commitment and Best-Efforts Offering Methods in IPOs: The Effect of Unsuccessful Offers, Journal of Financial Intermediation, 1998, 7: p. 60-90.

Benveniste, L., et al., Evidence of Information Spillovers in the Production of Investment Banking Services, Journal of Finance, 2003, 58: p. 577-608.

Edelen, RM., and GB. Kadlec, Issuer Surplus and the Partial Adjustment of IPO Prices to Public Information, Journal of Financial Economics, 2005, 77(2): p. 347-373.

Dunbar, CG., and SR. Foerster, Second Time Lucky? Withdrawn IPOs that Return to the Market, Journal of Financial Economics, 2008, 87(3): p. 610-635.

Bennouna, K., IPO Failures Around the World, 2015, Ph.D Thesis, Queensland University of Technology: Brisbane, Queensland, AUS. 
Nagata, K., Does Earnings Management Lead to Favorable IPO Price Formation or Further Underpricing? Evidence

From Japan, Journal of Multinational Financial Management, 2013, 23(4): p. 301-313.

Mccarthy, D., Michailova, S., and S. Puffer, A Critical View of Russia's IPO Market: A Sign of Success or a Reason for Caution?, Critical Perspectives on International Business, 2013, 9(1/2): p. 226-242.

Loughran, T., Ritter, J.R., and K. Rydqvist, Initial Public Offerings: International Insights, Pacific-Basin Finance Journal, 1994 upd. 2015, 2: p. 165-199.

Karaa, İE., and G. Akakçe, Türkiye'de Firmalarin Halka Arzdan Çekilme Nedenleri ve Sonuçları, Journal of Business Research Turk, 2017, 9(3): p. 375-392.

Dolvin, S., IPO Underpricing: The Owners' Perspective, Journal of Economics and Finance Education, 2013, 12(2): p. 1-8.

Dolvin, S. and B. Jordan, Underpricing, Overhang and the Cost of Going Public to Preexisting Shareholders, Journal of Business Finance and Accounting, 2008, 35: p. 434-458. 